\title{
PRIVATIZAÇÃO E MUDANÇAS ORGANIZACIONAIS
}

\author{
Por Ivan Beck Ckagnazaroff \\ Professor do CEPEAD/CAD/UFMG. \\ E-mail: ivanbeck@face.ufmg.br
}

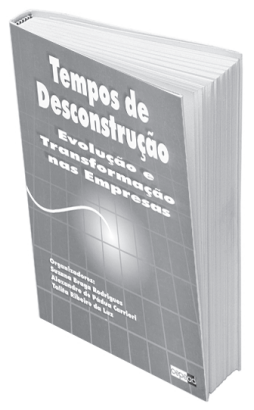

\section{TEMPOS DE DESCONSTRUÇÃO: EVOLUÇÃO E TRANSFORMAÇÃO NAS EMPRESAS}

De Suzana Braga Rodrigues, Alexandre de Pádua Carrieri e Talita Ribeiro da Luz (Organizadores). Belo Horizonte: CEPEAD/UFMG, 2003, 200 p.
O universo organizacional tem sido pródigo em gerar situações de grande interesse aos pesquisadores envolvidos no árduo trabalho de desvendar a lógica de unidades sociais constituídas. Nas últimas décadas, o trabalho desses investigadores ganhou fôlego em função das profundas e aparentemente irreversíveis transformações que atingiram o espaço produtivo global.

Tal fato fica evidente quando se observam, por exemplo, as profundas alterações na lógica do Estado. A partir da década de 1980, o Estado, duramente criticado quanto a sua eficiência, tamanho e presença em setores produtivos caracterizados como de interesse privado, viuse às voltas com uma crescente onda de privatizações de empresas públicas.
A transferência de empresas que estavam sob controle público para a esfera privada, por meio das ações de privatização, tornou-se um dos símbolos mais visíveis de uma época turbulenta e complexa.

Um dos setores que mais sofreu esse impacto foi o de telecomunicações. Esse campo rapidamente se tornou uma espécie de ícone, sendo responsável pela movimentação de grandes valores e de alterações no padrão tecnológico e de relações de trabalho. De um lado estavam os defensores dessa mudança, que apregoaram, entre outros aspectos, as vantagens da desregulamentação. De outro, estavam os críticos, entrincheirados em torno da defesa da soberania e da garantia de emprego e trabalho.

Argumentos a favor dessa nova configuração e contra ela ainda se fazem ouvir. E, em se tratando da realidade brasileira, que viveu o auge das privatizações na década de 1990, não seria diferente. Em meio a esse quadro, o interesse pelo setor e pelas empresas que o constituem tem levado ao surgimento de inúmeros trabalhos de cunho científico que tentam formular explicações que ajudam a entender algo ainda novo, mas ao mesmo tempo incerto e instigante.

Os autores do livro Tempos de Desconstrução: evolução e transformação nas empresas propõem uma leitura que pode interessar a diferentes estudiosos do campo administrativo. A obra busca elucidar algumas dimensões presentes no universo simbólico e concreto de uma grande empresa de telecomunica- 
ções que viveu a mudança em seu controle acionário, indo do público ao privado.

Ao estudar o caso da Telemig/ Telemar Minas sob ângulos distintos, os pesquisadores propõem um amplo esforço de análise das mudanças decorrentes da privatização. Centrada no período que vai de 1973 até 2001, essa coletânea contém artigos que transitam por diferentes temas. Transformação e coevolução organizacional, cultura e identidade, governança corporativa, competência e gestão de tecnologia são discutidos na perspectiva da investigação qualitativa.

Dividido em sete capítulos, o livro começa com a descrição e a justificativa do percurso metodológico adotado. O segundo capítulo trata da transformação e da co-evolução na Telemig, que se transformou em Telemar-Minas com o processo de privatização. Utilizando-se de um estudo longitudinal, percorre aproximadamente dezoito anos para explicar como se processaram as alterações na empresa, procurando contemplar diferentes dimensões analíticas, como, por exemplo, aspectos de natureza política e de gestão macroeconômica e tecnológica.

O terceiro capítulo analisa a governança corporativa da empresa no período de 1977 até 2000. É interessante destacar que a análise dos registros do conselho de administração evidenciou claramente a mudança de enfoque ao longo do tempo, acompanhando as exigências normativas e mercadológicas em curso. A análise identifica no período 1998-2000 uma atuação mais voltada para a estratégia, o controle e a avaliação gerencial, situação bem diferente do período que vai de 1973 a 1978, em que o conteúdo decisório estava voltado para o marco legal.
O quarto capítulo discute o uso de metáforas como maneira de perceber e analisar as identidades organizacionais, que são percebidas e entendidas de maneiras diversas pelos grupos organizacionais e que refletem disputas entre os atores envolvidos.

O quinto capítulo, por sua vez, utiliza o conceito de aprendizagem organizacional para discutir o gerenciamento de novos conhecimentos, considerando a transição de monopólio estatal, fortemente calcado na tecnologia, para um modelo de livre mercado, em que a mesma tecnologia é considerada um mero prérequisito para a sobrevivência da organização.

O sexto capítulo coloca em destaque a aquisição e o desenvolvimento de competências organizacionais e individuais e sua ligação com a lógica de competitividade.

O sétimo capítulo discute, a partir da perspectiva tecnológica, o processo de mudança de gestão ocorrido. Com uma trajetória bem-sucedida em criar uma base de conhecimentos tecnológicos por meio de sua área de $\mathrm{P} \& \mathrm{D}$, a organização tem na privatização a constatação de que era necessário voltar-se cada vez mais ao mercado, com a transição de um modelo fechado e de tecnologia nacional, para um mercado aberto com diferentes soluções tecnológicas e fornecedores competitivos.

O livro apresenta ainda, de maneira sintética, proposições para outras pesquisas, constituindo uma contribuição importante para pesquisadores ou interessados em temas ligados à lógica da evolução e da transformação. Em sua proposta, até certo ponto ousada, de "dissecar" a mudança organizacional, tendo como objeto uma importante empresa de telefonia nacional, cuja história é sintomática do quadro de modificações na estrutura produtiva, o livro traz uma inegável contribuição por sua diversidade temática.

Entretanto, fica uma sensação de ausência, manifestada quando se observa que alguns atores não receberam tratamento e reflexão adequados, como, por exemplo, os sindicatos, o que faz com que a análise perca força analítica, ao mesmo tempo em que evidencia sua perspectiva descritiva. Essa lacuna é relevante porque se sabe o importante papel representado pelo sindicato no período que antecede a privatização e também no período posterior à criação da nova empresa.

Adicionalmente, mesmo que seja possível identificar no livro pontos de interseção entre os diferentes capítulos e constituir um fio condutor para o entendimento da lógica do processo, ainda assim seria interessante que tivesse sido realizado um trabalho de homogeneização dos textos quanto ao seu estilo e formato, o que seria de grande valia ao leitor, na medida em que reforçaria a idéia de unidade.

Isso destaca uma importante reflexão acerca de obras coletivas, que englobam diferentes artigos: mesmo que tenham sido feitas sob a óptica de um tema ou de um objeto, como é o caso desse livro, correm o sério risco de serem vistas como simples "colagem", sem ordenamento ou lógica interna. Naturalmente, essa situação ocorre se não houver o devido nivelamento dos artigos que eventualmente façam parte de uma obra com tais características.

Com suas muitas forças e algumas fraquezas, Tempos de Desconstrução: evolução e transformação nas empresas é uma obra que se agrega ao esforço acadêmico de tentar compreender e explicar a lógica organizacional e seus desdobramentos históricos. 